\title{
Consequences of the Additional Polymerization on Knoop Microhardness of Direct Composite Resin
}

\author{
Consecuencias de la Polimerización Adicional sobre \\ Microdureza Knoop de la Resina Compuesta Directa
}

Rodrigo F. Carvalho*; Camila R. Faria*; Fernando L. G. Cruz ${ }^{* *}$ Júlio César Brigolini de Faria* \& Fabíola P. P. Leite ${ }^{* *}$

CARVALHO, R. F.; FARIA, C. R.; CRUZ, F. L. G.; FARIA, J. C.; B. \& LEITE, F. P. P. Consequences of the additional polymerization on knoop microhardness of direct composite resin. Int. J. Odontostomat., 7(1):93-98, 2013.

ABSTRACT: The following hypothesis was tested: direct composites additional polymerization improve the surface microhardness of direct composite resin Filtek Z250 (3M ESPE). We prepared 25 specimens ( $2 x 4 \mathrm{~mm})$ with a stainless steel mold. Resin specimens were randomly assigned into 5 groups ( $n=5 /$ per group): G1 - resin Filtek Z250 photoactivated 60 s; G2 - resin Filtek Z250 photoactivated $60 \mathrm{~s}+$ autoclave cycle to $134^{\circ} \mathrm{C}$ for 7 min at a pressure of $2.5 \mathrm{~kg} / \mathrm{cm} 3$; G3 - resin Filtek Z250 photoactivated $60 \mathrm{~s}+$ oven at $125^{\circ} \mathrm{C}$ for $7 \mathrm{~min}$; G4 - resin Filtek Z250 photoactivated $60 \mathrm{~s}+$ microwave for 3 min to the power of 450W; G5 - indirect resin Resilab photoactivated $60 \mathrm{~s}+$ supplementary furnace LUX GDS 4 min. The specimens were fabricated by a metal matrix, filled with resin in two increments and each increment polymerized according to their group. For polymerization of the last layer, we used a glass plate on a polyester strip. Then the specimens were evaluated for surface microhardness Knoop. Additional polymerization media resulted in significant differences among the groups $(p<0.05)$ (One-way ANOVA and Dunnett test, $p=0.05)$. The mean surface hardness Knoop (KHM) were as follows: G1:

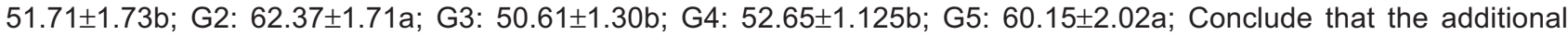
polymerization in autoclave increased the surface microhardness Knoop of composite resin evaluated. Hypothesis was partially confirmed.

KEY WORDS: composite resin, microhardness, polymerization.

\section{INTRODUCTION}

Recent advancements in operative dentistry have contributed for the development and evolution of different dental materials such as new composites and laboratory resin. These materials present an improvement of mechanical and esthetic characteristics that promote an increase of possibilities to indicate these materials.

The indications for using composites have become greater due to, principally, improvement of its physic-mechanical, chemical and esthetic features (Reis et al., 2007). It may be used anterior and posterior dental restorations (Beazoglou et al., 2007; Ferracane, 2011).

Rupture and wear of these composites are done by chewing forces and infiltration which is caused by stress of shrinkage in the polymerization. These events above are the main negative points which compromise the composites when used for replacing other materials in posterior dental restorations, especially in extensive cavities (Santana et al., 2009; Ferracane).

Several features of resin composites for direct use are inadequate when used for large restorations in posterior teeth, for example, higher shrinkage of polymerization. For this reason, resin system for indirect use was well developed (Kildal \& Ruyter, 1994).

Indirect restorations showed lower effects regarding shrinkages related to direct restorations. These indirect ones are made on the plaster die, silicon or polyether that decrease the shrinkage which is ranging for 2 to $4.3 \%$. In addition, this shrinkage occurs

* Department of Restorative Dentistry, Operative Dentistry Area, Dental School, State University of Júlio de Mesquita Filho, São José dos Campos, São Paulo, Brazil.

* Department of Restorative Dentistry, Brazil Dental School, University Federal of Juiz de Fora, Juiz de Fora, Minas Gerais, Brazil. 
outside of dental cavity (Ruyter, 1992). Secondary polymerization process (after polymerization) through heat, or heat and light treatment which these type of restorations have undergone lead to greater stability to this system. These composites give esthetic with large spectrum of colors, chroma and opacity, biocompatibility and tissue preservation. They are primarily indicated for inlay/onlay restorations, laminates, jacket crowns and for prosthesis over implants as well. When it is used on implants, it has got an advantage to put progressive load on the association prosthesis/implants that facilitates repairs done directly on the mouth, modification and adjustments of proximal contacts, and decrease occlusal stress in case of bruxism due to its resilience (Mandikos et al., 2001; Ferracane).

A possible way to minimize problems related to stress, infiltration and polymerization is to use indirect laboratory composite resin which is called Ceromers. It represents a large evolution for clinical practice being another alternative instead o using traditional indirect restorations materials such as metals, ceramics, metaloplastics and metaloceramics. On indirect technique, lost dental structure is reconstructed on a cast and the material is cured under controlled conditions in the laboratory. It allows the use of higher irradiances on light curing process that allow the light to penetrate deeper in the material used. These methods improve mechanical properties as hardness and flexion resistance due to an increase in the degree of conversion of monomers. In addition, it allows better occlusal and proximal accuracy facilitating an insert in the posterior cavity (Lovell et al., 2001).

Although, direct and indirect composites have similar chemical composition, the indirect ones present better mechanical properties (Kakaboura et al., 2003). It occurs due to high degree of conversion which is done by the use of different techniques of polymerization such as light curing, heat or / and nitrogen gas. All those techniques isolated or associated give uniformity in the polymerization of these materials (Bagis \& Rueggeberg, 2000). Usually, this additional heat treatment for indirect composites is done on special ovens associated to light and heat increasing the cost of indirect restorations. An alternative for this issue could be the use of direct composites to make the indirect ones. As a result, indirect teeth preparation as inlay, onlay and overlay are done with lower cost (Moraes et al., 2005). Recent studies (Arossi et al., 2007; Rodrigues et al., 2010) showed that satisfactory use of resin-based composites for direct use in indirect preparation. Consequently, some types of these composites for direct use have been more indicated for indirect restorations.

In the preparation of direct restorations with composites, polymerization is done by light cure, mean wave length is 470 nanometer. This type of curing the composites presents an advantage of being fast, safe and compatible cost comparing to restoration procedure. On the other hand, there are some limitations such as necessity of doing incremental polymerization of composites, lower and unequal conversion of monomers in different thickness of restoration body (Caughman \& Rueggeberg, 2002).

Several studies demonstrated that additional polymerization improves the mechanical characteristics of composites resulting in greater conversion of monomers in polymers. This additional procedure may be done by specific equipments. Usually, this equipment is found in dental laboratory as well as others, for instance, microwaves, stove and autoclave (Bagis \& Rueggeberg; Arossi et al.; Rodrigues et al.).

There is a consensus in the literature that, usually, additional heat treatment results in an improvement of mechanical characteristics of cured composites, such as superficial strength, resistance to traction and flexion, and color stability because greater residual monomers conversion (Bagis \& Rueggeberg; Lovell et al.; Santana et al.). Another benefit of this treatment is a contribution for relieving of tension in the polymerization and polishing procedures (Sideridou et al., 2004).

Temperature usually used for heating are ranged from 120 to $140^{\circ} \mathrm{C}$. Ideally, temperatures for this treatment should be higher than the temperature for vitrea transition (Tg). It allows a significant increase in mobility of polymeric chain which helps additional ligation and tension relief. However, a overheating may causes degradation of material and color changing of composite (Viljanen et al., 2007).

There is a hypothesis that additional heat treatment results in better mechanical properties of composites due to linking to monomers which did not react to light curing. The aim of this study is to evaluate an influence of different heating treatments in the superficial strength of two microhybrid resin-based composites. 


\section{MATERIAL AND METHOD}

Two microhybrid resin-based composites were selected in this study: Filtek Z250 (color A2, 3M ESPE, St Paul, MN, USA) and Resilab (color A2, Wilcos do Brazil Ltda., Petropolis, RJ, Brazil).

The characteristics and composition of each material are described in table I. In addition to conventional light curing of each resin, according to manufacturer, three additional heat treatment were used: (1) stove at $125^{\circ} \mathrm{C}$ of dry heat for 7 minutes; (2) autoclave in a cycle for $134^{\circ} \mathrm{C}$ for 7 minutes on 2.5 $\mathrm{KG} / \mathrm{cm} 3$ of pressure; and (3) microwave for 3 minutes with 450 w of power (Table I).

Specimen preparation. Twenty Five specimens $(n=$ 5) were made from a metallic matrix of aluminum (4 $\mathrm{mm} \varnothing$ and $2 \mathrm{~mm}$ of thickness). The composite was put on matrix in two increments and after excess removal of this material, a surface of composite was covered by a polyester strip (Dentsply, Petrópolis, RJ, Brazil), a glass cover slip and $500 \mathrm{~g}$ of weight were put for 20 seconds to eliminate porosities. After this period, cover slip and polyester strip were removed and samples were light activated according to the protocol for each group (Table II). Light activation was done for halogen light by using Optilux 501 (Demeton, Kerr, Orange, EUA), with mean irradiance of $850 \mathrm{maw} / \mathrm{cm}^{2}$.
According to each type of resin-based composite (direct or indirect use) and type of additional heat treatment were selected 5 groups, described in Table II.

After this light activation, the samples were included in acrylic resin and, the surfaces of each sample were flatted with carbide strips of silicon 1200 granulation (3M do Brazil, Sumaré, SP, Brazil) and kept for 24 hours in distilled water at $37^{\circ} \mathrm{C}$ previous to test of micro hardness. Five consecutive and equidistant readings $(50 \mu \mathrm{m})$ were obtained from surfaces of each sample. This micro hardness test (KHN) was done through microdurameter (Mitotoyo, Tokyo, Japan) using $50 \mathrm{~g}$ load for 15 seconds. After obtaining 5 readings for each specimen, an average was done for each sample.

Statiscally analysis. The data obtained from average of each sample was sent to an analysis of statistical variance using ANOVA methods, followed by Dunnett's test at the level of $5 \%$ of significance $(p<0,05)$

\section{RESULTS}

Table III presents an average and standard deviation of the composites tested. Distribution of values of microhardness of composites groups according to ANOVA test.

Table I. Name, type, main composition, volume of inorganic matrix and manufacturer of composites for direct or indirect using studied in this experiment.

\begin{tabular}{lcccc}
\hline Comercial Name & Type & \multicolumn{1}{c}{ Main composition } & Vol. Inorg matrix & Manufacturer \\
\hline FILTEK Z250 & Microhybrid & $\begin{array}{l}\text { Modified Bis-GMA Urethane, TEGDMA, } \\
\text { inorganic particles of } 0.01 \mathrm{~nm} \text { to } 3.5 \mathrm{~nm} \\
\text { (main size 0.6 nm) and light activators. }\end{array}$ & $60 \%$ & $\begin{array}{l}3 \mathrm{M} \text { ESPE, St Paul, } \\
\text { MN, USA }\end{array}$ \\
RESILAB & Microhybrid & $\begin{array}{l}\text { Bis-GMA, UDMA, TEGMA, Borosilicate } \\
\text { of aluminum, silicon, acid of high } \\
\text { dispersion, light activators and pigments }\end{array}$ & $53 \%$ & $\begin{array}{l}\text { Wilcos do Brazil } \\
\text { Ltda., Petrópolis } \\
\text { Brasil }\end{array}$ \\
\hline
\end{tabular}

Table II. Studied groups and light activation protocols, respectively.

\begin{tabular}{|c|c|}
\hline Group & Protocol of ligth activation \\
\hline$\overline{\mathbf{G 1}}$ & Composite Filtek Z250 light activate for 60 seconds with halogen light \\
\hline G2 & $\begin{array}{l}\text { Composite Filtek Z250 light activate for } 60 \text { seconds with halogen light }+ \text { sterilized in } 134^{\circ} \mathrm{C} \text { for } 7 \text { minutes } \\
\text { with } 2.5 \mathrm{KG} / \mathrm{cm}^{2} \text { pressure (Ortosíntese, São Paulo, SP, Brazil) }\end{array}$ \\
\hline G3 & $\begin{array}{l}\text { Composite Filtek Z250 light activate for } 60 \text { seconds with halogen light }+ \text { dry heat in stove, } 125^{\circ} \mathrm{C} \text { for } 7 \\
\text { minutes (Fabbe-Primar, model } 219 \text {, São Paulo, SP, Brazil). }\end{array}$ \\
\hline G4 & $\begin{array}{l}\text { Composit Filtek Z250 light activate for } 60 \text { seconds with halogen light }+ \text { microwave for } 3 \text { minutes with } 450 \\
\text { W power (Bluesky, São Paulo, SP, Brazil) }\end{array}$ \\
\hline G5 & $\begin{array}{l}\text { Indirect resin-based composite, light activated for } 3 \text { minutes for each increment and, later on for } 12 \\
\text { minutes in EDG LUX oven (EDG, São Carlos, SP, Brazil). }\end{array}$ \\
\hline
\end{tabular}

Bis-GMA = Bis-fenol-A-glycidilmethacrylate; UDMA = urethane dimethacrylate; TEGMA = Triethyleneglycol methacrylate. 
Table III. Mean and standard deviation of hardness Knoop of experimental groups according to complementary polymerization method.

\begin{tabular}{ll} 
Control group - G5 & $\mathbf{6 0 . 1 5}(\mathbf{2 , 0 2}) \mathbf{a}^{*}$ \\
\hline Group 1 & $51.71(1,73) \mathrm{b}$ \\
Group 2 & $62.37(1,71) \mathrm{a}$ \\
Group 3 & $50.61(1,30) \mathrm{b}$ \\
Group 4 & $52.65(1,25) \mathrm{b}$ \\
* $=$ control group &
\end{tabular}

By the test of Dunnett (5\%) it was possible to observe that Filtek Z250, the light activation methods without additional light on stove and microwave did not cause significant increase in microhardness. However, complementary activation method on autoclave was statistical different to other groups of direct composites $(p<0,05)$, obtaining similar results to the control group.

\section{DISCUSSION}

The characteristics of resin-based composites, such as hardness and strength, are important mechanical properties that promote a satisfactory clinical result to restoration material. These properties are determined for size, volume, particles distribution of load on the matrix and type of immersion (Ferracane).

The hardness of a material is a relative measurement of its strength to penetration when a constant specific load is applied. By definition, hardness is a capacity of a material to resist to penetration done by hard tip being direct proportional to mechanical strength and resistance to wear of a material (Yap et al., 2000; Yap et al., 2001). Changes in hardness influence on the state of reaction of setting time for each material and level of polymerization of material (Yap et al., 2001).

The indirect composites usually present higher level of polymerization compared to direct composites. It happens due to composites are polymerizated in special units enabling polymerization all restoration surfaces. Depends on the combination between light, heat, vacuum and pressure, polymerization unit may increase 10 to $20 \%$ the mechanical properties of indirect composites (Yoon et al., 2002).

The degree of polymerization of composites affects the hardness of resin matrix. If the degree of conversion of carbon double ligation is greater, higher values of hardness are reached (Asmussem, 1982). Complete polymerization of composites is determined by the degree of conversion of monomers in polymers indicating the number of metacrilate groups which react with another one in the conversion process. The factors which influence on the degree of conversion of composite are: curing time, color composite, temperature, composite thickness, type of load, distance between light and composite, quality of light, polymerization shrinkage (Albers, 2002).

The temperature on the polymerization process affects conversion and properties of polymers (Cook et al., 1997). Higher temperatures increase the radical and mobility o monomers resulting in greater global conversion and in better characteristics of restorations (Lovell et al., 2001). It has been demonstrated that temperature causes significant effect on final values of conversion of composites. Pre-heating microhybrid composite at $54^{\circ}$ or $60^{\circ} \mathrm{C}$ produces greater conversion enabling a decrease of exposure up to $75 \%$ lower, when comparing a conversion value similar to those ones obtained with exposure time recommended for room temperature (Daronch et al., 2005).

The results of this study showed that for composites of direct use, the methods of additional activation by stove or microwave showed no significant increase in micro hardness. This fact may be justified due to complementary activation might increase a conversion degree without any significant influence on increasing physic and mechanical characteristics of composites (Asmussem). Relating to additional polymerization by autoclave promotes a significant increase of micro hardness; it may explicated by a high temperature which a material was submitted. This increase in the micro hardness of direct composites that was done by different methods of complementary activation was also noted in other studies (Brosh et al., 1997; Bargis \& Rueggeberg).

When methods of complementary polymerization are done, the properties of materials may be improved (Soares et al., 2005). An increase of hardness is explained by increasing the conversion degree of composites submitted to temperatures which are similar to the temperature of vitrea transition. It leads to higher mobility of free monomers and greater flexibility of polymeric chain which possibilities new reaction between active radical. It promotes a major number of cross ligations of organic matrix making a composite with greater stability and hardness leading to higher strength (Bagis \& Rueggeberg). 
Additionally, on the complementary polymerization process by heating occurs evaporation approximately $1,3 \%$ of organic part of matrix (Bagis \& Rueggeberg).

The new composites have improved a technology of loading and show modification in organic matrix and higher degree of polymerization which improves its mechanical and physic characteristics (Bagis \& Rueggeberg; Borba et al., 2009; Miyazaki et al., 2009; Ferracane).
Observing the data of this current study, it is possible to conclude that complementary polymerization with autoclave increased a superficial hardness for direct use composites showing results statistically similar to indirect use composites.

ACKNOWLEDGEMENTS. The authors wish to thank for Institutional Program for Scientific Initiation Scholarships (PIBIC/Cnpq/UFJF - Protocol \#047.09.49) for the financial support.

CARVALHO, R. F.; FARIA, C. R.; CRUZ, F. L. G.; FARIA, J. C.; B. \& LEITE, F. P. P. Consecuencias de la polimerización adicional sobre microdureza Knoop de la resina compuesta directa. Int. J. Odontostomat., 7(1):93-98, 2013.

RESUMEN: La siguiente hipótesis fue probada: evaluar si la polimerización mejora aún más la dureza de la superficie de la resina compuesta directa Filtek Z250 (3M ESPE). Se prepararon 25 muestras (2x4mm) de un molde de acero inoxidable. Las muestras de resina fueron divididas al azar en 5 grupos $(n=5)$ : G1-resina Filtek Z250 polimerizado durante $60 \mathrm{~s}$; G2-polimerizado la resina Filtek Z250 durante $60 \mathrm{~s}$ y ciclo de autoclave $134^{\circ} \mathrm{C}$ durante $7 \mathrm{~min}$. a una presión de $2,5 \mathrm{~kg} /$ cm3; G3-resina Filtek Z250 polimerizado durante 60 s y cura para el horno a $125^{\circ} \mathrm{C}$ durante 7 min; G4-resina Filtek Z250 polimerizado por $60 \mathrm{~s}$ y curada durante $3 \mathrm{~min}$. con una potencia de microondas de 450W; G5-resina indirecta (Resilab) polimerizado $60 \mathrm{~s}$ y curada horno LUX/GDS durante $4 \mathrm{~min}$. Las muestras fueron fabricadas por una matriz metálica, rellena con resina en dos incrementos, y cada incremento de polimerizado de acuerdo a su grupo. Para la polimerización de la última capa se utilizó una placa de vidrio y una tira de poliéster. Luego se evaluó la microdureza Knoop de la superficie de las muestras. La polimerización adicional resultó en diferencias significativas entre los grupos $(p<0,05)($ One-way ANOVA

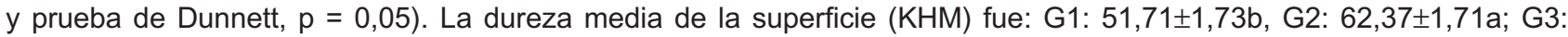
50,61 $\pm 1,30 b, G 4: 52,65 \pm 1,125 b ; G 5: 60,15 \pm 2,02^{a}$. Se concluye que la polimerización adicional con autoclave aumentó la microdureza de la superficie de resina evaluada. La hipótesis fue confirmada parcialmente.

PALABRAS CLAVE: resina compuesta, microdureza, polimerización.

\section{REFERENCES}

Albers, H. F. Resin Polymerization. In: Albers, H. F. (Ed.). Tooth-colored restoratives. Principles and techniques. $9^{\text {a }}$ Ed. London, BC Decker, 2002. pp.81-110.

Arossi, G. A.; Ogliari, F.; Samuel, S. M. W. \& Busato, A. L. S. Polimerização complementar em autoclave, microondas e estufa de um compósito restaurador direto. Rev. Odont. Ciênc., 22(56):177-80, 2007.

Asmussem, E. Restorative resins: hardness and strength vs. quantity of remaining double bonds. Scand. J. Dent. Res., 90(6):484-9, 1982.

Bagis, Y. H. \& Rueggeberg, F. A. The effect of post-cure heating on residual, unreacted monomer in a commercial resin composite. Dent. Mater., 16(4):244-7, 2000.

Beazoglou, T.; Eklund. S.; Heffley, D.; Meiers, J.; Brown, L. J. \& Bailit, $\mathrm{H}$. Economic Impact of. Regulating the Use of Amalgam Restorations. Public Health Rep., 122(5):65763, 2007.
Borba, M.; Della Bona, A. \& Cecchetti, D. Flexural strength and hardness of direct and indirect composites. Braz. Oral Res., 23(1):5-10, 2009.

Brosh, T.; Baharau, H.; Gross, O. \& Laufer, B. Z. The influence of surface loading and irradiation time during curing on mechanical properties of a composite. J. Prosthet. Dent., 77(6):573-7, 1997.

Caughman, W. F. \& Rueggeberg, F. A. Shedding new light on composite polymerization. Oper. Dent., 27(6):636-8, 2002.

Cook, W. D.; Simon, G. P.; Burchill, P. J.; Lau, M. \& Fitch, T. J. Curing kinetics and thermal properties of vinyl ester resins. J. Appl. Polym. Sci., 64(4):769-81, 1997.

Daronch, M.; Rueggeberg, F. A. \& De Goes, M. F. Monomer conversion of pre-heated composite. J. Dent. Res., 84(7):663-7, 2005. 
Ferracane, J. L. Resin composite - State of the art. Dental Mater., 27(1):29-38, 2011.

Kakaboura, A.; Rahiotis, C.; Zinelis, S.; Al-Dhamadi, Y.; Silikas, N. \& Watts, D. C. In vitro characterization of two laboratory-processed resin composites. Dent Mater., 19(5):393-8, 2003.

Kildal, K. K. \& Ruyter, I. E. How different curing methods affect the Kdegree of conversion of resin-based inlay/onlay materials. Acta Odontol. Scand., 52(5):31522, 1994.

Lovell, L. G.; Lu, H.; Elliott, J. E.; Stansbury, J. W. \& Bowman, C. N. The effect of cure rate on the mechanical properties of dental resins. Dent. Mater., 17(6):504-11, 2001.

Mandikos, M. N.; McGivney, G. P.; Davis, E.; Bush, P. J. \& Carter, J. M. A comparison of the wear resistance and hardness of indirect composite resins. J. Prosthet. Dent., 85(4):386-95, 2001.

Miyazaki, C. L.; Medeiros, I. S.; Santana, I. L.; Matos J.do R. \& Rodrigues Filho, L. E. Heat treatment of a direct composite resin: influence on flexural strength. Braz. Oral. Res., 23:241-247, 2009.

Moraes, D.; Rank, R. S. I. C. \& Imparato, J. S. P. Restoration of primary molars with indirect restoration with composite resin. Rev. Fac. Odontol. Univ. Passo Fundo, 10:51-4, 2005.

Reis, A.; Louguercio, A. D.; Bittencourt, D. D. \& Góes, M. F. Resinas Compostas. In:Materiais Dentários Diretos dos Fundmantos à Aplicação. São Paulo, Santos, 2007. pp.137-80.

Rodrigues, R. A.; Rebellato, C.; Bastos, R. A.; Santos, D. F. S. \& Filho, E. S. D. D. Análise da microdureza Knoop de quatro tipos de resina composta através do microdurômetro HVS-1000. Odontol. Clín.-Cient., 9(1):55-8, 2010.

Ruyter, I. E. Types of resin- based inlay materials and their properties. Int. Dent. J., 42(3):139-44, 1992.

Santana, I. L.; Lodovici, E.; Matos, J. R.; Medeiros, I. S.; Miyazaki, C. L. \& Rodrigues-Filho, L. E. Effect of experimental heat treatment on mechanical properties of resin composites. Braz. Dent. J., 20(2):205-10, 2009.

Sideridou, I.; Achilias, D. S. \& Kyrikou, E. Thermal expansion characteristics of light-cured dental resins and resin composites. Biomaterials, 25(15):3087-97, 2004.

Soares, C. J.; Pizi, E. C.; Fonseca, R. B. \& Martins, L. R. Mechanical properties of light-cured composites polymerized with several additional post-curing methods. Oper. Dent., 30(3):389-94, 2005.
Viljanen, E. K.; Skrifvars, M. \& Vallittu, P. K. Dendritic copolymers and particulate filler composites for dental applications: degree of conversion and thermal properties. Dent. Mater., 23(11):1420-7, 2007.

Yap, A. U.; Wong, M. L. \& Lim, A. C. The effect of polishing systems on microleakeage of tooth-colored restoratives. Part 2. Composite and polyacid-modified composite resins. J. Oral Rehabil., 27(3):205-10, 2000.

Yap, A. U.; Tan, S. H.; Wee, S. S.; Lee, C. W.; Lim, E. L. \& Zeng, K. Y. Chemical degradation of composite restoratives. J. Oral Rehabil., 28(11):1015-21, 2001.

Yoon, T. H.; Lee, Y. K.; Lim, B. S. \& Kim, C. W. Degree of polymerization of resin composites by different light sources. J. Oral Rehabil., 29(12):1165-73, 2002.

Correspondence to:

Profa. Dra. Fabíola Pessoa Pereira Leite

Rua Antônio Carlos Saraiva, 490, apt 501

Cascatinha.

CEP: 36033-345

Juiz de Fora - MG.

BRAZIL

Tel: +55 (32) 2102-3881

Email: fabíola.leite@ufjf.edu.br

Received: 21-06-2012

Accepted: 21-12-2012 